\title{
THE EFFECT OF ACUTE SOMATIC PAIN ON THE KILLING ACTIVITY OF NEUTROPHILS IN NEWBORN RATS
}

Alekseev $\mathrm{W}^{1 \otimes}$, Kade $\mathrm{AKh}^{2}$

${ }^{1}$ Rostov State Medical University, Rostov-on-Don, Russia

2 Kuban State Medical University, Krasnodar, Russia

The immune system is subject to all sorts of influences. Pain is one of them, accompanying an organism's existence. It is essential to be aware of and account for age-related characteristics of the innate immunity in order to adequately assess their dynamics in ontogenesis. The literature is scarce on the changes to the killing activity of neutrophils occurring in newborns in response to acute pain. The aim of this study was to detect potential changes to the phagocytic activity of neutrophils in response to an algogenic stimulus in newborn rats. The experiments were carried out in 3-5-day-old rats. Two groups were formed: the control group and the main group, in which acute pain was modelled. Blood samples were collected 2, 30-60 and 120-180 minutes after exposure to the algogenic stimulus. The microbicidal activity of neutrophils was measured using a spectrophotometric modification of the spontaneous/stimulated nitroblue tetrazolium (NBT) reduction test. The results were compared using the Mann-Whitney $U$ test. In the first hour following pain modeling, the stimulated NBT reduction test demonstrated an increase in the measured parameters from 71.5 to 87.4 a.u. $(p<0.001$ ); the spontaneous NBT reduction test showed an increase from 50.7 to 58.6 a.u. $(p<0.01) 30$ to 60 min after exposure. The most pronounced change of the microbicidal activity coefficient was observed 2 min after pain modeling, increasing from 1.40 to 1.72 a.u $(p<0.001)$. By the end of the experiment, the measured parameters approximated their initial values. During the analysis, we accounted for the fact that the neutrophil response to the algogenic stimulus was unfolding in the setting of microbial colonization occurring in newborns.

Keywords: pain, NBT test, newborns, neutrophils, neutrophil microbicidal activity

Acknowledgements: the authors thank Ovsyannikov VG, Head of the Department of Pathologic Physiology (Rostov State Medical University) and Boychenko AE, Professor at the Department of Pathologic Physiology, for their valuable advice and feedback; Aboyan IA, Chief Physician of the Clinical Diagnostic Center Health, for granting access to the laboratory equipment of the Center.

Author contribution: Alexeev W conducted the experiment, analyzed and interpreted the obtained results, wrote the manuscript; Kade AKh conceived and designed the study, revised the manuscript for intellectual content and made final corrections.

Compliance with ethical standards: the study was approved by the Ethics Committee of Rostov State Medical University (Protocol № 20/17 dated November 23, 2017).

$\triangle$ Correspondence should be addressed: Vladimir V. Alexeev

per. Nakhichevansky, 29, Rostov-on-Don, 344022; alexeev911@gmail.com

Received: 17.12.2019 Accepted: 07.01.2020 Published online: 20.01.2020

DOI: $10.24075 /$ brsmu.2020.002

\section{ВЛИЯНИЕ ОСТРОЙ СОМАТИЧЕСКОЙ БОЛИ НА КИЛЛИНГОВУЮ АКТИВНОСТЬ НЕЙТРОФИЛОВ НОВОРОЖДЕННЫХ КРЫС}

В. В. Алексеев ${ }^{1}$, А. Х. Каде ${ }^{2}$

1 Ростовский государственный медицинский университет, Ростов-на-Дону, Россия

${ }^{2}$ Кубанский государственный медицинский университет, Краснодар, Россия

Иммунная система претерпевает влияния различной природы. Один из факторов, сопровождающих жизнедеятельность организма, - боль. Знать и учитывать возрастные особенности факторов врожденного иммунитета необходимо для адекватной оценки изменения их параметров в онтогенезе. В литературных источниках недостаточно данных об особенностях изменения киллинговой активности нейтрофилов в ответ на острую боль у новорожденных. Целью работы было выявить изменения фагоцитарной активности нейтрофилов в ответ на краткосрочный алгогенный стимул у новорожденных крыс. Эксперимент проводили на 3-5-дневных крысятах. Были сформированы две группы: контрольная и экспериментальная с моделированием острого алгогенного воздействия. После моделирования осуществляли забор материала через 2, 30-60, 120-180 мин. Для оценки микробицидной активности нейтрофилов использовали спонтанный и стимулированный методы автоматизированного учета теста с нитросиним тетразолием (НСТ-теста). Сравнение данных проводили на основе U-критерия Манна-Уитни. Наблюдали повышение значений спонтанного НСТ-теста с 50,7 до 58,6 у. ед. через 30-60 мин ( $>$ < 0,01), а также стимулированного НСТ-теста с 71,5 до 87,4 у. ед. ( $<<0,001)$ в течение первого часа эксперимента. Максимально выраженное изменение коэфициента микробицидности наблюдали через 2 мин с 1,40 до 1,72 у. ед. (p < 0,001). К концу эксперимента показатели приближались к исходным значениям. При анализе результатов учитывали, что новорожденные крысята испытывают влияние со стороны микробной колонизации, на фоне которой развертывается реакция нейтрофилов на алгогенное раздражение.

Ключевые слова: боль, НСТ-тест, новорожденные, нейтрофилы, микробицидность нейтрофилов

Благодарности: В. Г. Овсянникову, заведующему кафедрой патологической физиологии РостГМУ и А. Е. Бойченко, профрессору кафедры патологической физиологии за ценные идеи и критические замечания. И. А. Абояну, главному врачу КДЦ «Здоровье» за предоставленную возможность использовать оборудование лаборатории

Вклад авторов: В. В. Алексеев - проведение экспериментальной и аналитической части исследования, анализ и интерпретация данных, написание рукописи; А. Х. Каде - разработка концепции и дизайна, проверка интеллектуального содержания, окончательное редактирование.

Соблюдение этических стандартов: исследование одобрено этическим комитетом РостГМУ (протокол № 20/17 от 23 ноября 2017 г.).

$\bowtie$ Для корреспонденции: Алексеев Владимир Вячеславович пер. Нахичеванский, д. 29, г. Ростов-на-Дону, 344022; alexeev911@gmail.com

Статья получена: 17.12.2019 Статья принята к печати: 07.01.2020 Опубликована онлайн: 20.01.2020

DOI: $10.24075 /$ vrgmu.2020.002 
There is a large body of evidence that immune responses can be elicited by stimuli other than antigens, including stress [1, 2], infrared light [3], LED light [4], magnetic fields [5], narcotic drugs [6], overtraining [7], etc. On this list, pain should not be an exception.

Alexeeva NS has convincingly demonstrated that neutrophils are involved in the acute algogenic process in adult rats. The reaction she observed was very pronounced but short-lived, which enabled her to define a functional mobilization syndrome in neutrophils primed for effective phagocytosis in case if exposure to a pain-evoking stimulus will escalate into tissue damage, infection, etc. [8].

There are grounds to believe that exposure of newborn rats to an algogenic stimulus will induce a complex of immune reactions, including changes to the phagocytic activity of neutrophils. Among all innate immunity factors, neutrophils have been shown to be the most sensitive to changes occurring in the intrauterine environment and after birth [9].

We searched the available literature for the effects of acute pain on the killing activity of neutrophils in newborn rats but found no relevant information. So, the aim of this study was to detect possible changes in the phagocytic activity of neutrophils in newborn rats in response to an algogenic stimulus.

\section{METHODS}

The study was carried out in newborn 3-5-day-old albino rats with an average weight of 12 to $14 \mathrm{~g}$. The animals were born and housed in standard facilities under a 12:12 light:dark cycle at a comfortable temperature of about $24^{\circ} \mathrm{C}$. The sex of the animals was not factored into. The experiments were conducted in the summer.

Functional activity of neutrophils was tested in 32 experiments. The animals were divided into two unequal groups: the main group $(n=24)$ and the control group $(n=8)$. In the main group, acute pain was modelled by applying an electric stimulus to the skin at the tail base. The intensity of the stimulus was 3 to 4 points on the Waldman-Vasiliev scale modified by Ovsyannikov [10]. Exposure duration was 2 minutes.

After acute somatic pain modeling, the animals were decapitated. Blood samples were collected into test tubes containing $100 \mathrm{u} / \mathrm{ml}$ heparin 2, 30-60, 120-180 min after the experiment. Blood was diluted 1:2 with Hanks' balanced salts solution (PanEco; Russia). Then, the samples were centrifuged with a Ficoll-Verographin density gradient $(1.083 \mathrm{~g} / \mathrm{ml})$ for $45 \mathrm{~min}$ at 1,500 rpm. Microbicidal activity of neutrophils was measured using a spectrophotometric modification of the test of spontaneous/endotoxin-induced nitroblue tetrazolium (NBT) reduction [11]. The test is based on the ability of almost colorless NBT to be reduced by oxygen radicals to deep blue diformazan.

Fifty $\mu$ l of $0.5 \%$ NBT solution were added to each microplate well containing the cell suspension. For the spontaneous reduction test, $50 \mu \mathrm{l}$ of PBS $(\mathrm{pH}=7.0)$ were added to the even rows of the microplate. For endotoxin-stimulated reduction, $50 \mu \mathrm{l}$ of $0.1 \%$ latex solution with particle size of $1.5 \mu \mathrm{m}$ (PanEco; Russia) were added to the odd rows. Then the microplate was incubated in an incubator for 24 min at $37^{\circ} \mathrm{C}$. The microplate was read in a Multiskan Sky spectrophotometer (THERMO FISHER SCIENTIFIC; USA) at $540 \mathrm{~nm}$. Mean optical density was measured in 4 wells ( 2 for the spontaneous reduction test and 2 for the stimulated reduction test). The results were expressed as arbitrary units ( 1 a.u. $=1,000$ optical density units). Then, the microbicidal activity coefficient (MAC) was calculated by dividing the mean optical density in the stimulated-reduction wells by the mean optical density in the spontaneous-reduction wells.

Statistical analysis was conducted in Microsoft Office Excel 2010 Pro (Microsoft; USA), STATISTICA 10.0 (Statsoft; USA). We tested the normality of quantitative data distribution using the Lilliefors-corrected Kolmogorov-Smirnov and ShapiroWilk tests; calculated median values $(\mathrm{Me})$, the upper and lower quantiles $\left(Q_{0.25}, Q_{0.75}\right)$, the minimum (Min) to maximum (Max) value range for the data that did not fit into the normal distribution; compared the data using the Mann-Whitney $U$ test. The critical level of significance (p) was assumed to be 0.05 . The results are presented in this work as $M e\left[Q_{0.25} ; Q_{0.75}\right]$ (Min-Max).

\section{RESULTS}

The spontaneous NBT reduction test produced the following results in the control group of newborn rats: $\mathrm{Me}_{\text {sD NBT }}=50.7$ a.u. $\left[Q_{0.25}=49.3\right.$ a.u.; $Q_{0.75}=52.7$ a.u.], Min = 48.9 a.u. and Max $=$

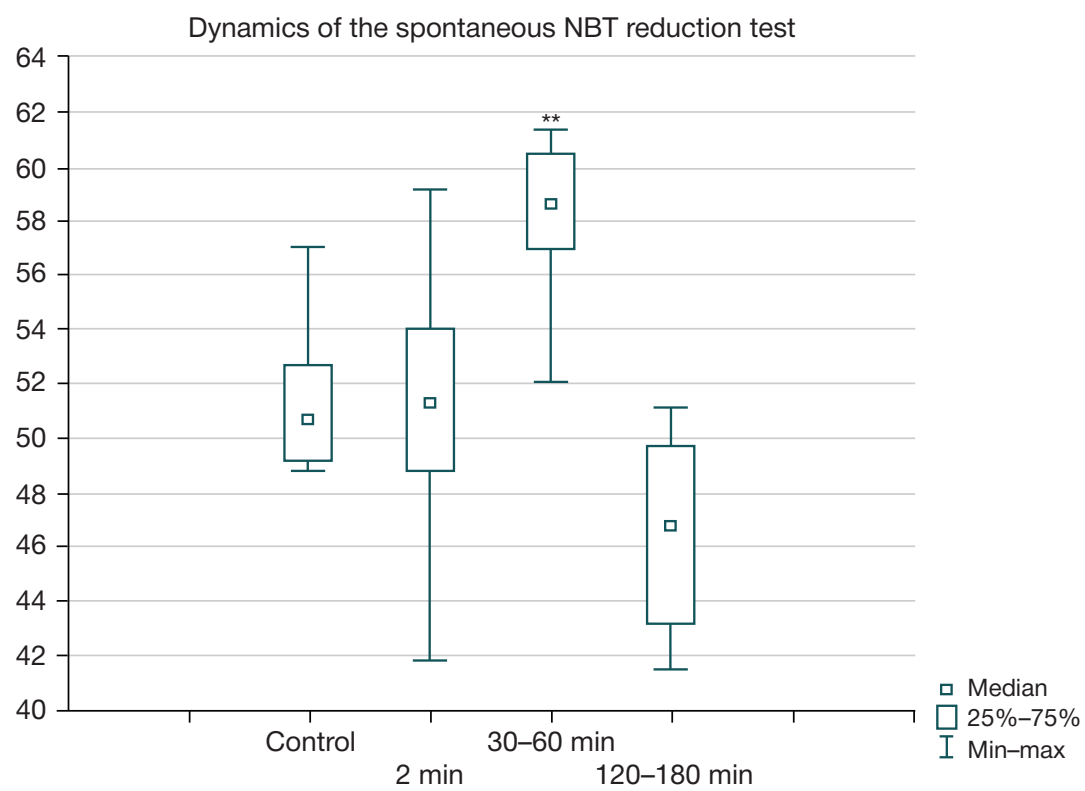

Fig. 1. Dynamics of the spontaneous NBT reduction test in newborn rats before and after exposure to the algogenic stimulus. ${ }^{\star \star}$ — differences are significant between the main group and the control animals $(p \leq 0.05)$ 
57.1 a.u. In the main group, Me ${ }_{\text {sp NBT }}$ reached 51.4 a.u. $\left[\mathrm{Q}_{0.25}=48.8\right.$ a.u.; ${ }_{\mathrm{Q} .75}=54.1$ a.u.], Min was 41.9 a.u. and Max was 59.1 a.u. 2 minutes after the algogenic stimulus was applied. In the first hour after exposure, Me sp NBT $_{\text {was }}$ 58.6 a.u. $\left[Q_{0.25}=57.0\right.$ a.u.; $Q_{0.75}=60.5$ a.u.], Min was 52.1 a.u. and Max was 61.3 a.u. In the third hour of observation, Me ${ }_{\text {sp NBT }}$ equaled 46.9 a.u. $\left[Q_{0.25}=43.3\right.$ a.u.; $Q_{0.75}=49.8$ a.u.], Min was 41.6 a.u. and Max was 51.1 a.u.

Statistical analysis revealed that algogenic stimulation was activating spontaneous NBT reduction. The differences were significant between the control and the main group and also between the initial response to electrical stimulation and the response recorded $30-60$ min after it $(p<0.01)$. Median values yielded by the experiment demonstrate that distribution between the upper and lower quantiles was even; the upper quantile approximated the maximum peak value in the sample. It should be noted that the observed reaction was short-lasting and quickly depletable. Two hours after pain modeling, the median values of the spontaneous NBT reduction test were lower than in the control group $(p=0.05)$ (Fig. 1).

The stimulated NBT reduction test produced the following results in the control group: $\mathrm{Me}_{\text {st NBT }}=71.5$ a.u. $\left[\mathrm{Q}_{0.25}=68.0\right.$ a.u.; $Q_{0.75}=73.4$ a.u.], $M i n=67.2$ a.u., $M a x=76.5$ a.u. These values were higher than in the spontaneous reduction test.

Immediately after algogenic stimulation, all parameters of the stimulated NBT reduction test started to grow, indicating that neutrophils were highly primed to ward off a potential microbial attack. Specifically, Me ${ }_{\text {st NBT }}$ was 90.4 a.u. $(p<0.001)$ $\left[Q_{0.25}=87.8\right.$ a.u.; $Q_{0.75}=93.0$ a.u.], Min was 84.8 a.u. and Max was 96.3 a.u. Neutrophils retained a high level of microbicidal activity for an hour following exposure to the stimulus: $\mathrm{Me}_{\text {st NBT }}=$ 87.4 a.u. $(p<0.001)\left[Q_{0,25}=78.8\right.$ a.u.; $Q_{0,75}=89.9$ a.u.], Min $=$ 77.6 a.u. and $\operatorname{Max}=93.0$ a.u.

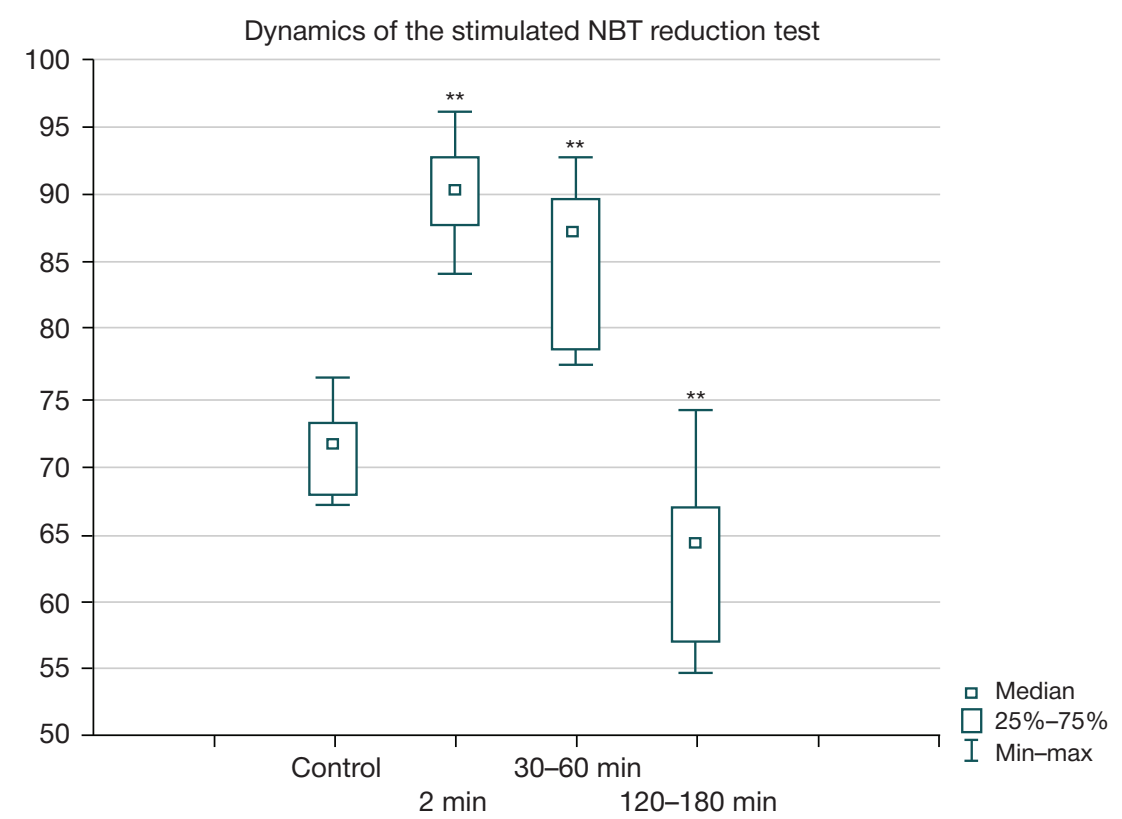

Fig. 2. Dynamics of the stimulated NBT reduction test in newborn rats before and after exposure to the algogenic stimulus. ${ }^{* *}-$ differences are significant between the main group and the control animals $(p \leq 0.05)$

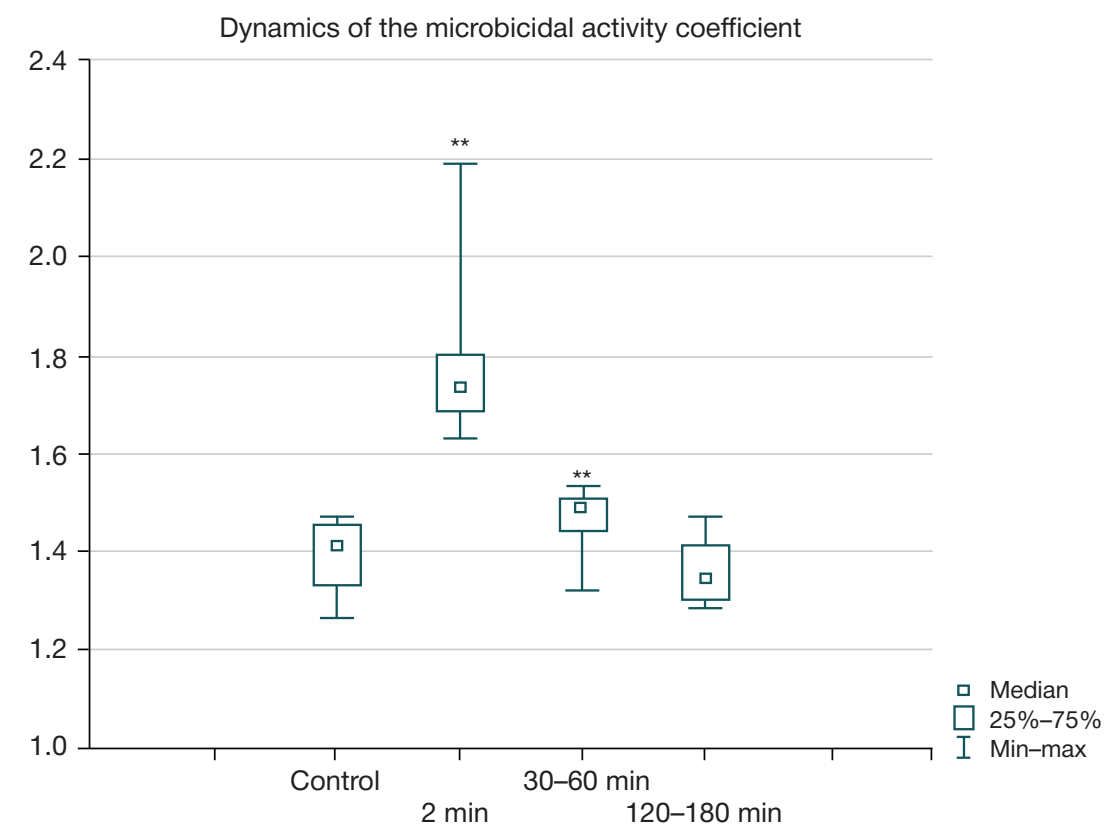

Fig. 3. Dynamics of the microbicidal activity coefficient in newborn rats before and after exposure to the algogenic stimulus. ${ }^{* \star}-$ differences are significant between the main group and the control animals $(p \leq 0.05)$ 
Similar to the spontaneous NBT reduction test, 2 hours after pain modeling microbicidal activity reserves were depleted. $\mathrm{Me}_{\text {st NBT }}$ declined to 64.5 a.u. $(p<0.05)\left[\mathrm{Q}_{0,25}=57.2\right.$ a.u.; $\mathrm{Q}_{0,75}=$ 66.9 a.u.], Min decreased to 54.8 a.u. and Max was 74.1 a.u. (Fig. 2).

Knowing that the modified NBT test reflects the metabolic activity of neutrophils, specifically the oxygen-dependent mechanisms underlying their microbicidal effect, we should consider the opinion of its developers about the killing effect of neutrophils being best described by the microbial activity coefficient [12]; the coefficient is calculated by dividing the value of the stimulated NBT reduction test by the value of the spontaneous NBT reduction test. Me ${ }_{\text {maccontr }}=1.40$ a.u. $\left[Q_{025}\right.$ = 1.33 a.u.; $Q_{0.75}=1.45$ a.u.], $\operatorname{Min}=1.26$ a.u., $\operatorname{Max}=1.47$ a.u.

Two minutes after algogenic stimulation, MAC was significantly increased relative to the control value: $\mathrm{Me}_{\text {MAC }}=$ 1.72 a.u. $(p<0.001)\left[Q_{0.25}=1.68\right.$ a.u.; $Q_{0.75}=1.80$ a.u.], Min $=$ 1.63 a.u., $\operatorname{Max}=2.19$ a.u.

In the first hour after exposure, MAC was declining but was still above the values demonstrated by the control group: $\mathrm{Me}_{\text {MAC }}=$ 1.49 a.u. $\left[Q_{025}=1.44\right.$ a.u.; $Q_{075}=1.51$ a.u.], $\operatorname{Min}=1.32$ a.u., $\operatorname{Max}=$ 1.53 a.u.

By the end of the experiment, MAC did not differ significantly from the control values: $M e_{\text {MAC }}=1.34$ a.u. $\left[Q_{0.25}=1.30\right.$ a.u.; $Q_{0.75}=1.41$ a.u.], $\operatorname{Min}=1.28$ a.u., $\operatorname{Max}=1.47$ a.u. (Fig. 3).

\section{DISCUSSION}

A theoretical framework for understanding the impact of acute somatic pain on the phagocytic activity of neutrophils can only be developed in the context of neuro-immuno-endocrine interactions. Today, there is no doubt that neurogenic, endocrine and immune mechanisms all contribute to maintaining the body's homeostasis. The pathogenesis of pain or at least its initial stage is similar to the unfolding of stress. Stress is not always caused by pain but acute pain is always a stress, which is why stress hormones, specifically catecholamines, are synthesized in response to an algogenic stimulus. The model used in this study was previously exploited to demonstrate that 2 min after applying an algogenic stimulus, adrenalin and noradrenaline levels, whose ratio is age-dependent, increased in peripheral blood [12].

In another study, the electrophysiological analysis revealed that excitation of nociceptors and signal transmission via the ascending pathways led to the activation of brain structures involved in the control of involuntary functions, the hypothalamus in the first place, and synchronized with the activation of neutrophil granulocytes [13].

Apart from neurogenic noradrenaline, the adrenal medulla releases adrenaline and noradrenaline into the bloodstream. These hormones ultimately find their targets and the subsequent events follow a typical stress scenario. Neutrophils are one of such targets; they were shown express both $\alpha$ - and $\beta$ - adrenergic receptors [14], which was later confirmed by another study [15]. In our experiments, we observed an increase in the phagocytic activity by the end of the first hour following exposure to the stimulus (in the spontaneous NBT reduction test); in the stimulated NBT reduction test, the phagocytic activity started to increase by minute 2 following pain induction. But by the end of the experiment the phagocytic activity had been restored to the initial level. This can be explained by the activation of beta-adrenoreceptors of neutrophils [16]. Also, it is important to remember that stress is accompanied by elevated production of glucocorticoids that inhibit the functional activity of neutrophils [17]

The obtained MAC values suggest that neutrophils of newborn rats can exert killing activity $[11,18]$.

We have shown that algogenic stimulation leads to both spontaneous and stimulated NBT reduction, as well as to an increase in the killing activity of neutrophils, which, on the surface, seems to be inconsistent with the conventional concept of functional immaturity of phagocytes in newborns.

One of possible explanations for our findings might lie in the acknowledgement of the early formed capacity of neutrophils to produce a superoxide [19] when their protective potential is reduced [20].

In the neonatal period, the organism of the newborn, including skin, mucosal lining, gastrointestinal and genitourinary tracts and lungs, is actively colonized by microbiota. This process is short-lasting and intense. Although this fact has long entered textbooks, it is still explored in the academic literature from different perspectives [21-23]. But one opinion that is held firm is that an intense antigen load cannot but mobilize the factors of immune defense, still allowing for the fact that the mechanisms of adaptive immunity are immature at the time the child is born. One should agree that innate immunity factors in general and neutrophils in particular (as the most labile cells) play a key role in the first-line defense in the neonatal period. The discovery of the bacterial translocation corroborates this hypothesis [24].

Thus, on the one hand, the innate immunity of newborns is stimulated by microbial colonization and, on the other hand, acts as a background for the unfolding response to a different nonantigen stimulus, which in our case was an algogenic stimulus.

\section{CONCLUSIONS}

1. The killing activity of neutrophils is initiated and enhanced in response to an acute algogenic stimulus. 2. In newborn rats, an antimicrobial response to short-term acute pain demonstrated by neutrophils is short-lived and quickly depletable. 3 . The results of this study broaden our knowledge of metabolic activity of neutrophils in response to acute pain in newborns. Our findings can be used in pain research, for adequate assessment of changes occurring in ontogenesis and for prevention of adverse effects pain can have.

\section{References}

1. Garkavi LKh, Ukolova MA, Kvakina EB. Zakonomernost' razvitiya kachestvenno otlichayushchikhsya obshchikh nespetsificheskikh adaptatsionnykh reaktsiy organizma. Nauchnoe otkrytie № 158 ot 3.10.1969. Russian.

2. Shilova YuA, Shilov DYu, Shilov Yul. Vliyanie stressa na aktivnost leykotsitov perifericheskoy krovi. Uspekhi sovremennogo estestvoznaniya. 2010; (7): 54-5. Russian.
3. Zhevago NA, Samoilova KA, Obolenskaya KD. The regulatory effect of polychromatic (visible and infrared) light on human humoral immunity. Photochemical \& Photobiological Sciences. 2004; 3 (1): 102-8.

4. Ogneva Ol, Osikov MV, Gizinger OA, Fedosov AA. Mekhanizm izmeneniya immunnogo statusa pri eksperimental'nom desinkhronoze $v$ usloviyakh svetodiodnogo osveshcheniya. 
Sovremennye problemy nauki i obrazovaniya. 2015; (3): 184 Russian.

5. Zyuzya EV, Kalutskiy PV, Ivanov AV. Vliyanie sochetannogo primeneniya krovezamenitelya perftoran i antibiotika tsefataksim na sostoyanie immunologicheskikh pokazatey perifericheskoy krovi $v$ usloviyakh modelirovaniya infitsirovannoy rany vozdeystviya na organizm postoyannogo magnitnogo polya. Vestnik novykh meditsinskikh tekhnologiy. Elektronnoe izdanie. 2013; (1): 80. Russian.

6. Akperov EK, Tsygan VN, Stepanov AV. Sostoyanie nespetsificheskoy rezistentnosti u lits, zloupotreblyayushchikh narkoticheskimi veshchestvami. Psikhofarmakologiya biologicheskaya narkologiya. 2005; 5 (2): 963-5. Russian.

7. Bazarin KP, Savchenko AA, Kovalev VN, Lazarenko NA, Landenok AV. Neyrosetevoe modelirovanie vliyaniya faktorov sportivnoy deyatel'nosti na funktsional'nuyu aktivnost' neytrofilov krovi u kvalifitsirovannykh sportsmenov. Acta Biomedica Scientifica. 2017; 2 (114): 62-8. Russian.

8. Alekseeva NS. Mekhanizmy izmeneniya fagotsitarnoy aktivnosti leykotsitov pri ostroy vistseral'noy boli [dissertatsiya]. Rostov-naDonu, 2008. Russian.

9. Abramova MV. Faktory vrozhdennogo immuniteta u samok krys i ikh potomstva pri normal'nykh rodakh i bolevoy stimulyatsii [dissertatsiya]. Rostov-na-Donu, 2019. Russian.

10. Ovsyannikov VG. Ocherki patofiziologii boli. Rostov-na-Donu: Tsvetnaya pechat', 2003; 148 s. Russian.

11. Kiseleva EP, Polevshchikov AV. Metod avtomatizirovannogo ucheta NST-testa. Klinicheskaya laboratornaya diagnostika. 1994; (4): 27-9. Russian.

12. Zajnab AM. Vozrastnye osobennosti monoaminergicheskoj reakcil pri ostroj boli [dissertacija]. Rostov-na-Donu, 1995. Russian.

13. Stepanova ES. Vlijanie pereohlazhdenija na funkcional'nuju aktivnost' lejkocitov [dissertacija]. Syktyvkar, 2010. Russian.

14. Heumann D, Visher TL. Immunomodulation by alpha2macroglobulin and alpha2-macroglobulin proteinase complexes: the effect on the T lymphocyte response. Eur J Immunol. 1988; (18): 755.

\section{Литература}

1. Гаркави Л. Х., Уколова М. А., Квакина Е. Б. Закономерность развития качественно отличающихся общих неспецифических адаптационных реакций организма. Научное открытие № 158 от 3.10.1969.

2. Шилова Ю. А., Шилов Д. Ю., Шилов Ю. И. Влияние стресса на активность лейкоцитов периферической крови. Успехи современного естествознания. 2010; (7): 54-55.

3. Zhevago NA, Samoilova KA, Obolenskaya KD. The regulatory effect of polychromatic (visible and infrared) light on human humoral immunity. Photochemical \& Photobiological Sciences. 2004; 3 (1): 102-8.

4. Огнева О. И., Осиков М. В., Гизингер О. А., Федосов А. А. Механизм изменения иммунного статуса при экспериментальном десинхронозе в условиях светодиодного освещения. Современные проблемы науки и образования. 2015; (3): 184

5. Зюзя Е. В., Калуцкий П. В., Иванов А. В. Влияние сочетанного применения кровезаменителя перфторан и антибиотика цесатаксим на состояние иммунологических показатей периферической крови в условиях моделирования инфицированной раны и воздействия на организм постоянного магнитного поля. Вестник новых медицинских технологий. Электронное издание. 2013; (1): 80.

6. Акперов Э. К., Цыган В. Н., Степанов А. В. Состояние неспецифической резистентности у лиц, злоупотребляющих наркотическими веществами. Психофармакология и биологическая наркология. 2005; 5 (2): 963-5.

7. Базарин К. П., Савченко А. А., Ковалев В. Н., Лазаренко Н. А. Ландёнок А. В. Нейросетевое моделирование влияния факторов спортивной деятельности на функциональную активность нейтрофилов крови у квалифицированных
15. Nicholls AJ, Wen Wen S, Hall P, Hickey MJ, Wong CHY. Activation of the sympathetic nervous system modulates neutrophil function. J Leukoc Biol. 2018; (103): 295-309.

16. Kachina II, Shilov DYu, Shilov Yul. Vlijanie agonista betaadrenoreceptorov geksoprenalina sul'fata in vitro na fagocitarnuju aktivnost' nejtrofilov perifericheskoj krovi zdorovyh ljudej. Mezhdunarodnyj zhurnal prikladnyh i fundamental'nyh issledovanii. 2012; (1): 72-3. Russian.

17. Kolesnikova NV, Nesterova IV, Chudilova GA. Rannie i otdalennye jeffekty vlijanija jekzogennogo gidrokortizona na sistemu nejtrofil'nyh granulocitov laboratornyh myshej. Gematologija i transfuziologija. 1999; 44 (5): 36-40. Russian.

18. Zinkin VYu, Godkov MA. Sposob kolichestvennoy otsenki kislorodzavisimogo metabolizma neytrofil'nykh granulotsitov cheloveka. Klinicheskaya laboratornaya diagnostika. 2004; (8): 26-9. Russian.

19. Chirkin AA. Biokhimiya s osnovami gennoy inzhenerii: ucheb. posobie. Vitebsk: UO "VGU im. P. M. Masherova", 2010; 182 s. Russian.

20. Klimenko NA, Shelest MA. Funktsional'naya aktivnost' neytrofilov perifericheskoy krovi pri khronicheskom bronkhite. Nauchnye vedomosti Belgorodskogo gosudarstvennogo universiteta. Seriya: Meditsina. Farmatsiya. 2013; 11 (154); Vypusk 22: 129-31. Russian.

21. Zhelnina TP, Brezhneva NI, Osyaev NYu. Analiz struktury mikroflory novorozhdennykh. Infektsiya i immunitet. 2016; 6 (3): 26. Russian.

22. Belyaeva IA, Bombardirova EP, Mitish MD, Potekhina TV, Kharitonova NA. Ontogenez i dizontogenez mikrobioty kishechnika u detey rannego vozrasta: triggernyy mekhanizm narusheniy detskogo zdorov'ya. Voprosy sovremennoy pediatrii. 2017; 16 (1): 29-38. Russian.

23. Nikolaeva IV, Tsaregorodtsev AD, Shaykhieva GS. Formirovanie kishechnoy mikrobioty rebenka i faktory, vliyayushchie na etot protsess. Rossiyskiy vestnik perinatologii i pediatrii. 2018; 63 (3): 13-8. Russian.

24. Nikitenko NI, Zakharov VV, Borodin AV. Rol' translokatsii bakteriy v patogeneze khirurgicheskoy infektsii. Khirurgiya. 2001; (2): 63-6. Russian. спортсменов. Acta Biomedica Scientifica. 2017; 2 (114): 62-8.

8. Алексеева Н. С. Механизмы изменения фагоцитарной активности лейкоцитов при острой висцеральной боли [диссертация]. Ростов-на-Дону, 2008.

9. Абрамова М. В. Факторы врожденного иммунитета у самок крыс и их потомства при нормальных родах и болевой стимуляции [диссертация]. Ростов-на-Дону, 2019.

10. Овсянников В. Г. Очерки патофизиологии боли. Ростов-наДону: Цветная печать, 2003; 148 с.

11. Киселева Е. П., Полевщиков А. В. Метод автоматизированного учета НСТ-теста. Клиническая лабораторная диагностика. 1994; (4): 27-9

12. Зайнаб А. М. Возрастные особенности моноаминергической реакции при острой боли [диссертация]. Ростов-на-Дону: 1995.

13. Степанова Е. С. Влияние переохлаждения на функциональную активность лейкоцитов [диссертация]. Сыктывкар, 2010.

14. Heumann D, Visher TL. Immunomodulation by alpha2macroglobulin and alpha2-macroglobulin proteinase complexes: the effect on the T lymphocyte response. Eur J Immunol. 1988; (18): 755

15. Nicholls AJ, Wen Wen S, Hall P, Hickey MJ, Wong CHY. Activation of the sympathetic nervous system modulates neutrophil function. J Leukoc Biol. 2018; (103): 295-309.

16. Качина И. И., Шилов Д. Ю., Шилов Ю. И. Влияние агониста бета-адренорецепторов гексопреналина сульсата in vitro на фагоцитарную активность нейтрофилов периферической крови здоровых людей. Международный журнал прикладных и фундаментальных исследований. 2012; (1): 72-3.

17. Колесникова Н. В., Нестерова И. В., Чудилова Г. А. Ранние и отдаленные эффекты влияния экзогенного гидрокортизона на систему нейтросильных гранулоцитов лабораторных 
мышей. Гематология и трансфузиология. 1999; 44 (5): 36-40.

18. Зинкин В. Ю., Годков М. А. Способ количественной оценки кислородзависимого метаболизма нейтросильных гранулоцитов человека. Клиническая лабораторная диагностика. 2004; (8): 26-9.

19. Чиркин А. А. Биохимия с основами генной инженерии: учеб. пособие. Витебск: УО «ВГУ им. П. М. Машерова», 2010; 182 с.

20. Клименко Н. А., Шелест М. А. Функциональная активность нейтрофилов периферической крови при хроническом бронхите. Научные ведомости Белгородского государственного университета. Серия: Медицина. Фармация. 2013; 11 (154); Выпуск 22: 129-131.

21. Желнина Т. П., Брежнева Н. И., Осяев Н. Ю. Анализ структуры микрофлоры новорожденных. Инфекция и иммунитет. 2016; 6 (3): 26.

22. Беляева И. А., Бомбардирова Е. П., Митиш М. Д., Потехина Т. В., Харитонова Н. А. Онтогенез и дизонтогенез микробиоть кишечника у детей раннего возраста: триггерный механизм нарушений детского здоровья. Вопросы современной педиатрии. 2017; 16 (1): 29-38.

23. Николаева И. В., Царегородцев А. Д., Шайхиева Г. С. Формирование кишечной микробиоты ребенка и факторы, влияющие на этот процесс. Российский вестник перинатологии и педиатрии. 2018; 63 (3): 13-8.

24. Никитенко Н. И., Захаров В. В., Бородин А. В. Роль транслокации бактерий в патогенезе хирургической инсекции. Хирургия. 2001; (2): 63-6. 